\title{
Effect of different concentrations of protein on the digestive system of juvenile silver catfish
}

[Efeito de diferentes concentrações de proteína sobre o sistema digestivo de juvenis de jundiá]

\author{
J.F.B. Melo ${ }^{1}$, L.M. Lundstedt ${ }^{2}$, G. Moraes ${ }^{3}$, L.A.K.A. Inoue ${ }^{4}$ \\ ${ }^{1}$ Universidade Federal do Vale do São Francisco - UNIVASF - Petrolina, PE \\ ${ }^{2}$ EMBRAPA Pesca e Aquicultura - Palmas, TO \\ ${ }^{3}$ Universidade Federal de São Carlos - UFSCAR - São Carlos, SP \\ ${ }^{4}$ EMBRAPA Amazônia Ocidental - Manaus, AM
}

\begin{abstract}
Aspects of digestion in juvenile silver catfish Rhamdia quelen fed with four levels of protein (20, 27, 34 and $41 \%$ ) were studied. The studied traits were digestive enzymes (nonspecific proteases, trypsin, chymotrypsin, amylase and lipase) and weight gain. The experiment lasted 60 days; 160 juvenile catfish with initial body weight of 32 grams were transferred to the experimental system of 500L tanks with recirculated and thermostatized water. The average weight of silver catfish increased with dietary protein and $41 \%$ of crude protein (CP) was accepted as the best one. Gastric protease activity increases with the $\mathrm{CP}$ level. The intestinal alkaline protease reached the peak at $27 \% \mathrm{CP}$ and the highest activities were observed in the anterior section of the gut (AS). The trypsin peak was observed at $34 \% \mathrm{CP}$ in the AS and medium section of the gut (MS). Amylase and lipase activities were inverse to the dietary CP and the highest values were observed in AS. In conclusion, the digestive enzymes of catfishes are responsive to the dietary protein level. The dietary CP required for highest weight gain of juvenile silver catfish is $41 \%$.
\end{abstract}

Keywords: digestive enzymes, nutrition, fish, Rhamdia quelen

\section{RESUMO}

Foram estudados aspectos digestivos de juvenis de jundiá Rhamdia quelen alimentados com quatro níveis de proteína (20,27, 34 e $41 \%$ ). As características estudadas foram enzimas digestivas (proteases inespecíficas, tripsina, quimiotripsina, amilase e lipase) e ganho de peso. O período experimental foi de 60 dias; 160 juvenis de jundiá com peso médio inicial de 32 gramas foram transferidos para um sistema experimental de tanques de 500L, com recirculação de água termostatizada. O peso médio dos jundiás aumentou com o teor de proteínas da dieta até $41 \%$ de proteína bruta $(P B)$, valor esse considerado o melhor. A atividade de protease gástrica aumentou com o nível de PB. A protease alcalina intestinal atingiu o pico em $27 \%$ de $P B$ e as maiores atividades foram observadas na secção anterior do intestino (SA). O pico de tripsina foi observado com $34 \%$ de PB na SA e na secção média do intestino (SM). As atividades de amilase e lipase foram inversas ao teor de PB, e os valores mais elevados foram observados na SA. Em conclusão, as enzimas digestivas de jundiá são responsivas ao nível de proteína da dieta. O teor mais alto de PB da dieta necessário ao maior ganho de peso em juvenis de jundiá é $41 \%$.

Palavras-chave: enzimas digestivas, nutrição, peixe, Rhamdia quelen

\section{INTRODUCTION}

Among the macronutrients, proteins play a pivotal role in many biological functions. Fish, in particular, present meaningful requirements of dietary protein. This fact deserves special attention when the diets are formulated in intensive fish rearing systems. Nutritional needs must look at many aspects, such as: fish species, metabolic demands, growth phase and potential to adapt to environmental changes.

Recebido em 28 de março de 2011

Aceito em 31 de janeiro de 2012

E-mail: melojfb@yahoo.com.br 
Several studies have evaluated the enzyme behavior of the gastrointestinal tract of fish correlated to the use of nutrients aiming for the best understanding of the processes involving nutrition, growth, health and performance on the fish husbandry (Kuz'mina, 1981; Dabrowski et al., 1992; Lundstedt et al., 2004; Xiong et al., 2010). In spite of reports on digestive enzymes of fish affirming they are adaptable to dietary protein contents (Fish, 1960; Kawai and Ikeda, 1972; Mukhopadhyay, 1977; Hofer and Schiemer, 1981), this fact remained as a matter of discussion for a while. Glass et al., (1989) assumed that the knowledge on the exact amount and specificity of digestive enzymes should be a tool to precisely predict the digestive process in fish. This assumption has been observed and accepted in studies with warm water tropical fishes (Lundstedt et al., 2004; De Almeida et al., 2006; Correa et al., 2007). Thereby, to improve fish digestions and nutrient intake the adaptive range of responses must be established (Segner et al., 1989).

The South American catfish "jundia" (Rhamdia quelen) is a Neotropical Siluriform-Pimelodidae reported from Mexico to Argentina (Silfvergrip, 1996). This species displays several farming qualities and belongs to a group of eleven species, presently included in the Rhamdia genus. The $R$. quelen fish is an omnivorous species which accepts a number of different nutrients, including artificial feeding, since hatching. It presents good survival rates, and fast growth and development (Piaia et al., 1997; Melo et al., 2002). Nowadays, there is little information concerning digestion in species from the Rhamdia genus. In the present study, adaptations of the digestive profile of $R$. quelen fed distinct contents of crude protein $(\mathrm{CP})$ were investigated.

\section{MATERIAL AND METHODS}

Juvenile jundiá with initial average weight of $44.98 \mathrm{~g} \pm 13.32$ and $16.92 \mathrm{~cm} \pm 1.44$ length were held in four $2.000 \mathrm{~L}$ tanks with filtered, aerated and temperature-controlled water in a closed system. Forty fish per tank were fed isocaloric diets (4500kcal gross energy $/ \mathrm{kg}$ ) with 20 , 27,34 and $41 \%$ of crude protein (CP). The nutrient composition was previously determined (Table 1) and the diet ingredients were analyzed according to the Official... (1990). The fish were fed twice a day at the rate of $10 \%$ of the biomass and sampled on the $60^{\text {th }}$ day. Ten fish were sampled per treatment for enzyme assays and growth evaluation through the expression:

$G=\bar{x}_{F w}-\bar{x}_{I w}$ where $\left(G=\right.$ growth; $\bar{x}_{F w}=$ average final weight; $\bar{x}_{I w}=$ average initial weight).

The water quality was preserved through continuous recirculation, mechanic filtration through bio-beds and constant aeration. The water conditions were monitored and maintained in the course of the experiments as: temperature $25^{\circ} \mathrm{C} \pm 1$; $\mathrm{pH} 7.2$; dissolved oxygen $5.4 \mathrm{mg} / \mathrm{L}$; alkalinity $42 \mathrm{mg} / \mathrm{L}$ and ammonia $0.12 \mathrm{mg} / \mathrm{L}$. Biological variability was minimized using fish from the same strain. No death was observed in the whole experimental period.

Fish were sampled, anaesthetized with $100 \mathrm{mg} / \mathrm{L}$ of benzocaine (Inoue et al., 2003), gauged for size and weight, and blood samples were withdrawn from the caudal vein. Then the fish were killed through cervical pinch and samples of white muscle, kidney and liver were collected. Plasma aliquots were separated after blood centrifugation at $4^{\circ} \mathrm{C}$ for $10 \mathrm{~min}$ at $5000 \times \mathrm{G}$. The samples were immediately frozen in liquid nitrogen and kept at $-20^{\circ} \mathrm{C}$. The digestive tract was excised, divided into stomach, anterior, middle and posterior intestine, and stored at $20^{\circ} \mathrm{C}$.

The water quality was preserved through continuous recirculation, mechanic filtration through bio-beds and constant aeration. The water conditions were monitored and maintained in the course of the experiments as: temperature $25^{\circ} \mathrm{C} \pm 1$; $\mathrm{pH} 7.2$; dissolved oxygen $5.4 \mathrm{mg} / \mathrm{L}$; alkalinity $42 \mathrm{mg} / \mathrm{L}$ and ammonia $0.12 \mathrm{mg} / \mathrm{L}$. Biological variability was minimized using fish from the same strain. No death was observed in the whole experimental period. 
Table 1. Ingredients and analyzed composition of the experimental diets

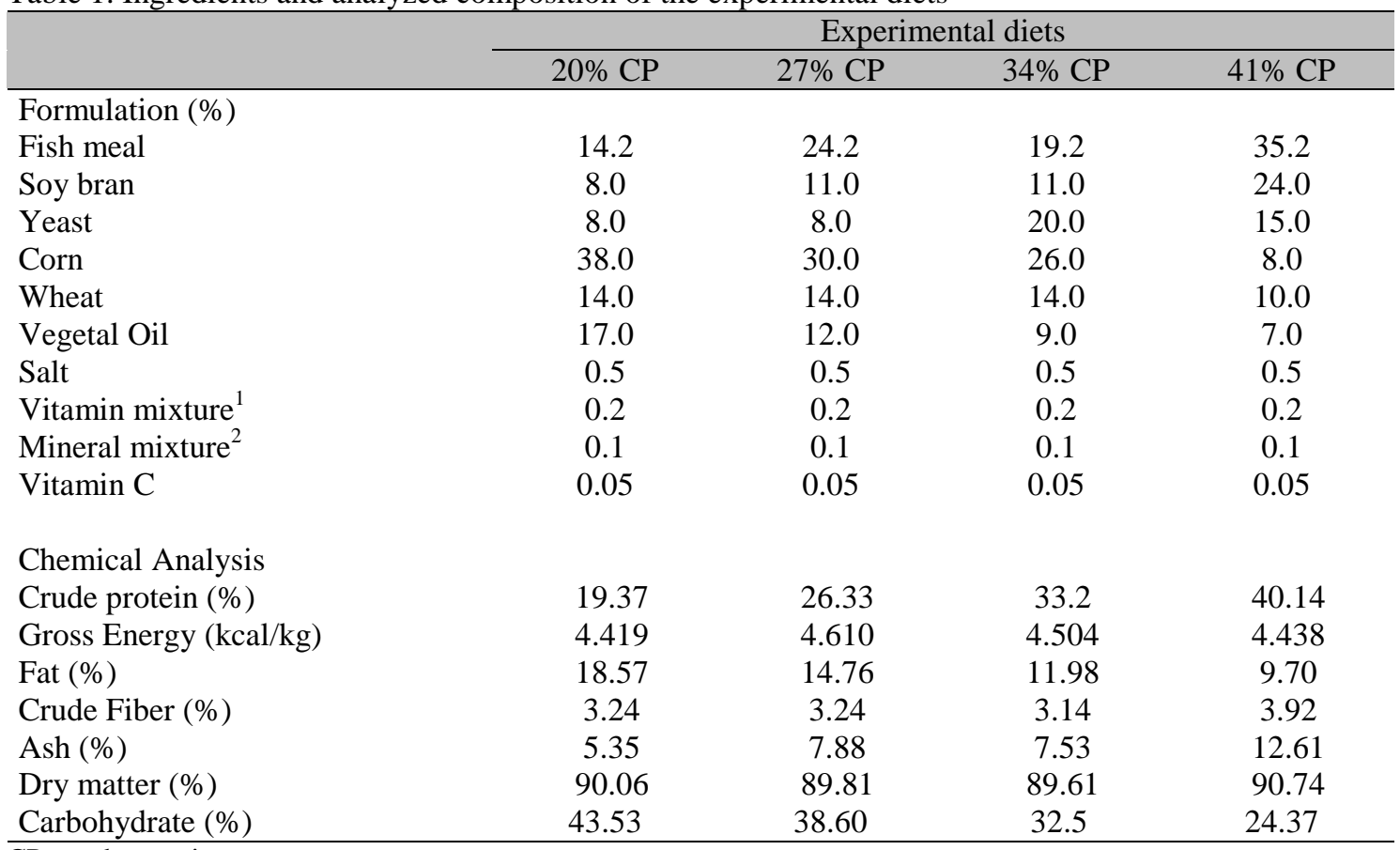

CP: crude protein;

${ }^{1}$ Composition of vitamin mixture/kg diet: Vitamin A 10.000 UI. E 50mg. D 3 2000UI. K-3 25mg. B 12 50mg. Thiamine 15mg. Riboflavin 35mg. Pyridoxine $10 \mathrm{mg}$. Biotin 250mg. Folic acid 5mg. Acid Pantothenic 60mg. Niacin 60mg. Choline 120g. Antioxidante 50g.

${ }^{2}$ Composition of mineral mixture/kg diet: Iron 40mg. Copper $12.5 \mathrm{mg}$. Zinc 30mg. Cobalt $1 \mathrm{mg}$. Iodo $1.4 \mathrm{mg}$ e Selenium $0.2 \mathrm{mg}$.

Fish were sampled, anaesthetized with $100 \mathrm{mg} / \mathrm{L}$ of benzocaine (Inoue et al., 2003), gauged for size and weight, and blood samples were withdrawn from the caudal vein. Then the fish were killed through cervical pinch and samples of white muscle, kidney and liver were collected. Plasma aliquots were separated after blood centrifugation at $4^{\circ} \mathrm{C}$ for $10 \mathrm{~min}$ at $5000 \times \mathrm{G}$. The samples were immediately frozen in liquid nitrogen and kept at $-20^{\circ} \mathrm{C}$. The digestive tract was excised, divided into stomach, anterior, middle and posterior intestine, and stored at $20^{\circ} \mathrm{C}$.

Samples from each gastrointestinal section were homogenized in an ice bath at a ratio of 1:10 (tissue:homogenization buffer) with a Teflon pestle of a motor-driven tissue-cell disrupter. The homogenization buffer solution was $0.02 \mathrm{M}$ Tris/0.01M phosphate $\mathrm{pH} 7.0$ in v/v glycerol. The homogenates were centrifuged at $11000 \times \mathrm{G}$ for $3 \mathrm{~min}$ and the supernatants (crude homogenate) were used as the enzyme resource. The protein content of the homogenates was determined colorimetrically at 660nm (Lowry et al., 1951) and albumin solution was used as standard.

Enzymes were previously assayed in the different sections of the gut to optimize the $\mathrm{pH}$ and temperature reaction, the incubation time, enzyme aliquot, and substrate saturation. Enzyme reaction mixture for Non-specific Acid Protease was $1 \%$ casein in $0.1 \mathrm{M}$ glycine $/ \mathrm{HCl}$ (pH 2.0) with the proper aliquot of crude homogenate. After incubation for $30 \mathrm{~min}$ at $30^{\circ} \mathrm{C}$ the reaction was stopped by $15 \%$ TCA (trichloroacetic acid) solution. The reaction mixture was centrifuged at $14400 \times \mathrm{G}$ for $3 \mathrm{~min}$ and the optical density of the supernatant was determined at 280nm (Walter, 1984). Tyrosine was used as standard and one unit was defined as the amount of enzyme to hydrolyze $1 \mu \mathrm{mol}$ of substrate per minute. Specific activity is expressed in units per $\mathrm{mg}$ of protein (U/mg protein). Enzyme reaction mixture for Nonspecific Alkaline Proteases in the intestine sections was: $1 \%$ azocasein in $0.1 \mathrm{M}$ Tris- $\mathrm{HCl}$ 
( $\mathrm{pH}$ 8.5) with proper aliquot of crude homogenate. After incubation for 30 minutes at $30^{\circ} \mathrm{C}$ the reaction was stopped by $15 \%$ TCA solution. The samples were centrifuged at $14400 \times \mathrm{G}$ for $3 \mathrm{~min}$; $1 \mathrm{~mL}$ was transferred to $1 \mathrm{~mL}$ of $1.3 \mathrm{~N} \mathrm{NaOH}$ and kept for $15 \mathrm{~min}$ at room temperature. The optical density was read at 440nm (Sarath et al., 1989). One unit of enzyme activity was defined as the amount of enzyme to hydrolyze $1 \mu \mathrm{mol}$ of substrate/min. Specific activity is expressed in units/mg of protein (U/mg protein).

Both trypsinolytic and chymotrypsinolytic activities were determined according to Hummel (1959) at $25^{\circ} \mathrm{C}$. The reaction mixture for Trypsin was $1.04 \mathrm{mM}$ TAME (p-toluenesulfonyl-Larginine ethyl ester) and $0.01 \mathrm{M} \mathrm{CaCl}_{2}$ in $0.2 \mathrm{M}$ Tris $\mathrm{pH}$ 8.1. The reaction product was followed at $247 \mathrm{~nm}$. One unit of enzyme was established as the amount to hydrolyze $1 \mu \mathrm{mol}$ of TAME/min. (corresponding to $1 \mu \mathrm{mol}$ of arginine $/ \mathrm{min}$ ) and the specific activity was expressed in unit/mg of protein (U/mg protein). The reaction mixture for Chymotrypsin was $0.001 \mathrm{M}$ BTEE (N-benzoill-Ltyrosine ethyl ester), $\mathrm{CaCl}_{2} 0.10 \mathrm{M}$ in $0.10 \mathrm{M}$ TRIS- $\mathrm{HCl} \mathrm{pH}$ 7.8. The reaction product was followed at $256 \mathrm{~nm}$. One unit of enzyme was defined as the amount to hydrolyze $1 \mu \mathrm{mol}$ of $\mathrm{BTEE} / \mathrm{min}$ (corresponding to $1 \mu \mathrm{mol}$ of tyrosine/min) and the specific activity was expressed in unit/mg of protein (U/mg of protein).

Amylase reaction mixture was 5\% starch solution in $0.2 \mathrm{M}$ citrate-phosphate buffer $\mathrm{pH} 7.0$ with $0.5 \% \mathrm{NaCl}$ and suitable aliquot of tissue homogenate (Bernfeld, 1995). The mixture was incubated for $15 \mathrm{~min}$. at $37^{\circ} \mathrm{C}$. Reaction was stopped by addition of $5 \% \mathrm{ZnSO}_{4} / 0.3 \mathrm{~N} \mathrm{Ba}(\mathrm{OH})_{2}$ (v:v) solution and the precipitate removed by centrifugation at $3000 \times \mathrm{G}$ for $2 \mathrm{~min}$. Free glucose concentration was quantified (Park and Johnson 1949) and 1 unit was defined as the amount of enzyme to produce $1 \mu \mathrm{mol}$ of reducing sugar/min. The specific activity was expressed in unit/milligram of protein (U/mg protein).

Lipase activity was assayed according to Albro et al. (1985). Suitable aliquots of homogenate were incubated with $0.4 \mathrm{mM}$ p-nitrophenyl myristate in $24 \mathrm{mM}$ ammonium bicarbonate $\mathrm{pH}$ 7.8, containing $0.5 \%$ Triton $\mathrm{X}-100$ as emulsifier.
Control reactions were run without enzyme and/or substrate. Reaction was stopped after $30 \mathrm{~min}$ by addition of $25 \mathrm{mM} \mathrm{NaOH}$ and the absorbance was read at $405 \mathrm{~nm}$. One unit was defined as the amount of enzyme to hydrolyze $1 \mu \mathrm{mol}$ of substrate/min and the specific activity was expressed unit/milligram of protein $(\mathrm{U} / \mathrm{mg}$ protein).

The experimental design was established as incomplete blocks formed by four treatments and ten repetitions per treatment. The enzymes average activities were analyzed as the variance and compared through Tukey's test. The growth rate and fish performance analyses were evaluated through descriptive statistics for $\mathrm{P}<0.05$.

\section{RESULTS AND DISCUSSION}

The weight of silver catfish fed increasing levels of protein increased significantly $(\mathrm{P}<0.05)$ over 60 days. The protein content required for optimum weight gain was found to be $41 \% \mathrm{CP}$. The average weight increased from 63.48 to $73.12,73.28,77.72$ and 97.72 grams with the increasing levels of dietary protein. Increase of dietary CP usually results in growth rate and weight increase within specific ranges (Melo et al., 2006; McGoogan and Gatlin III, 1999). Although considerable progress has been made in determining nutritional requirements for maximum growth of fish, it is important to consider that dietary manipulations may also influence other responses that are of aquacultural importance such as digestive enzyme activities.

In the stomach, the unspecific acid proteolytic activity followed the levels of dietary protein (Table 2). In the anterior, middle and posterior section of the gut (AS, MS and PM) the alkaline protease activity increased from 20 to $27 \% \mathrm{CP}$, and the highest activities were observed in the AS. The stomach presented alkaline proteolytic activity and the highest values were observed for $27 \% \mathrm{CP}$. In the AS and MS of the gut trypsin activity increased from 20 to $34 \%$ CP. In the gut, chymotrypsin activity was proportional to the increase of dietary protein. Amylase and lipase activities were proportionally converse to the content of dietary $\mathrm{CP}$, and the highest values were observed in the AS. 
Table 2. Digestive enzyme activities in the gastrointestinal sections of Rhamdia quelen with different dietary compositions. The values are means SD for $n=10$; significant differences $(\mathrm{P}<0.05)$ are presented by distinct letters

\begin{tabular}{|c|c|c|c|c|c|c|c|}
\hline & $\begin{array}{l}\mathrm{CP} \\
\%\end{array}$ & $\begin{array}{c}\text { Acid } \\
\text { proteolytic } \\
\text { U/mg protein }\end{array}$ & $\begin{array}{c}\text { Alkalina } \\
\text { proteolytic } \\
\text { U/mg protein }\end{array}$ & $\begin{array}{l}\text { Trypsin } \\
\text { U/mg } \\
\text { protein }\end{array}$ & $\begin{array}{c}\text { Chymotripsin } \\
\text { U/mg } \\
\text { protein }\end{array}$ & $\begin{array}{l}\text { Amylase } \\
\text { U/mg } \\
\text { protein }\end{array}$ & $\begin{array}{l}\text { Lipase } \\
\text { U/mg } \\
\text { protein }\end{array}$ \\
\hline \multirow{4}{*}{ Stomach } & 20 & $9.64 \mathrm{~d} \pm 3.67$ & \multirow{4}{*}{ 年 } & $0.33 \mathrm{a} \pm 0.06$ & $0.34 \pm 0.01$ & $0.08 a \pm 0.03$ & $0.32 \mathrm{a} \pm 0.06$ \\
\hline & 27 & $19.78 \mathrm{c} \pm 4.61$ & & $0.31 \mathrm{a} \pm 0.05$ & $0.39 \pm 0.01$ & $0.05 b \pm 0.02$ & $0.31 \mathrm{a} \pm 0.05$ \\
\hline & 34 & $27.21 \mathrm{~b} \pm 4.61$ & & $0.35 \mathrm{a} \pm 0.05$ & $0.82 \pm 0.01$ & $0.02 c \pm 0.01$ & $0.35 \mathrm{a} \pm 0.05$ \\
\hline & 41 & $43.46 \mathrm{a} \pm 9.89$ & & $0.36 a \pm 0.08$ & $1.03 \pm 0.08$ & $0.02 c \pm 0.02$ & $0.33 \mathrm{a} \pm 0.08$ \\
\hline \multirow{4}{*}{$\begin{array}{l}\text { Anterior } \\
\text { intestine }\end{array}$} & 20 & \multirow{4}{*}{ - } & $15.02 b \pm 2.91$ & $2.12 \mathrm{a} \pm 0.47$ & $3.51 \mathrm{~b} \pm 0.85$ & $0.19 \mathrm{a} \pm 0.03$ & $20.59 a \pm 3.61$ \\
\hline & 27 & & $25.60 \mathrm{a} \pm 2.91$ & $3.21 \mathrm{~b} \pm 0.50$ & $6.14 \mathrm{a} \pm 0.96$ & $0.14 b \pm 0.03$ & $13.61 \mathrm{~b} \pm 2.98$ \\
\hline & 34 & & $22.96 a \pm 2.77$ & $3.31 \mathrm{~b} \pm 0.49$ & $5.78 \mathrm{a} \pm 1.01$ & $0.08 c \pm 0.02$ & $8.54 c \pm 1.35$ \\
\hline & 41 & & $18.24 \mathrm{~b} \pm 2.96$ & $2.16 \mathrm{a} \pm 0.62$ & $3.92 \mathrm{~b} \pm 0.93$ & $0.07 \mathrm{c} \pm 0.01$ & $8.33 c \pm 1.76$ \\
\hline \multirow{4}{*}{$\begin{array}{l}\text { Middle } \\
\text { intestine }\end{array}$} & 20 & \multirow{4}{*}{ - } & $5.38 \mathrm{~b} \pm 2.12$ & $0.56 \mathrm{~b} \pm 0.14$ & $5.75 \mathrm{~b} \pm 1.08$ & $0.05 a \pm 0.02$ & $6.21 \mathrm{a} \pm 1.21$ \\
\hline & 27 & & $13.35 \mathrm{a} \pm 4.44$ & $0.99 b \pm 0.17$ & $11.1 \mathrm{a} \pm 1.96$ & $0.04 \mathrm{a} \pm 0.01$ & $4.49 b \pm 0.92$ \\
\hline & 34 & & $12.85 \mathrm{a} \pm 3.53$ & $1.51 \mathrm{a} \pm 0.54$ & $12.4 \mathrm{a} \pm 1.69$ & $0.02 b \pm 0.008$ & $1.89 \mathrm{c} \pm 0.56$ \\
\hline & 41 & & $9.79 b \pm 3.18$ & $1.17 \mathrm{ab} \pm 0.38$ & $10.98 \mathrm{a} \pm 2.02$ & $0.02 b \pm 0.007$ & $1.73 c \pm 0.96$ \\
\hline \multirow{4}{*}{$\begin{array}{l}\text { Posterior } \\
\text { intestine }\end{array}$} & 20 & \multirow{4}{*}{ - } & $4.11 \mathrm{~b} \pm 1.89$ & $1.28 \mathrm{~b} \pm 0.29$ & $0.65 c \pm 0.20$ & $0.06 a \pm 0.005$ & $10.84 \mathrm{a} \pm 0.82$ \\
\hline & 27 & & $8.91 \mathrm{a} \pm 2.16$ & $1.63 \mathrm{a} \pm 0.39$ & $2.79 \mathrm{~b} \pm 0.68$ & $0.04 a b \pm 0.007$ & $5.46 \mathrm{~b} \pm 0.88$ \\
\hline & 34 & & $9.69 \mathrm{a} \pm 1.64$ & $1.29 a b \pm 0.36$ & $5.15 a \pm 0.99$ & $0.03 b \pm 0.005$ & $3.48 \mathrm{c} \pm 1.10$ \\
\hline & 41 & & $7.82 \mathrm{a} \pm 2.81$ & $1.31 \mathrm{ab} \pm 0.28$ & $4.82 \mathrm{a} \pm 1.01$ & $0.03 b \pm 0.004$ & $1.67 \mathrm{~d} \pm 1.13$ \\
\hline
\end{tabular}

The activity of the most digestive enzymes of the gastrointestinal tract of fish may change with the alimentary habit (Hofer and Shiemer, 1981; Kuz'mina and Smirnova, 1992). Pepsin is the main protease in the stomach of fishes; it has been reported in several species such as Anguilla japonica (Morishita et al., 1964), Tilapia mossambica (Fish, 1960; Nagasse, 1964), Oncorhynchus mykiss (Kitamikado and Tachino, 1960), Ictalurus sp (Nordlie, 1966; Smith, 1967) Dicentrachus labrax (Cuvier-Péres, 2001) and many other species. The optimum $\mathrm{pH}$ activity of pepsin is usually between 2.0 and 3.3 (Fänge and Grove, 1969; Lovell, 1988; Kuz'mina, 1991, Xiong et al. 2011), however its proteolytic activity has been reported in a larger $\mathrm{pH}$ range, varying from 1.5 to 8.5 (Kuz'mina, 1991). The responsiveness of pepsin to environmental factors such as light, husbandry and nutrient variation has been previously reported in fish (Kapoor et al., 1975; Cuvier-Péres, 2001). Pepsin from jundiá was responsive to dietary $\mathrm{CP}$. This kind of response observed in jundia suggests that this enzyme ensures a plentiful utilization of the ingested protein. The source of protein, either animal or vegetal, may influence the yield of digestive processes in fish. Not only may the level of dietary CP affect the enzyme response of the digestive tract, but the kind or source of protein can. However, some species are not affected. The pepsin activity of tambaqui Colossoma macropomum, is not influenced by vegetal or animal protein (Kohla et al., 1992). In this particular study, jundiá was also unaffected by the source of protein since the effects observed were for fish fed wheat or soy, as well as animal protein.

The alkaline proteases observed in the digestive tract of jundiá showed greater enzymatic activities in the anterior section of the intestine. Similar results are reported in other species such as Gptosternum maculatum (Xiong et al., 2011). In rainbow trout the alkaline proteases are also responsive to dietary protein (Kawai and Ikeda, 1972). That response is straightly related to the protein content. The unspecific alkaline proteolytic activity observed along all the intestine of jundia is probably due chiefly to the presence of trypsin and chymotrypsin, since the substrate azocasein is a target of both enzymes. These enzymes were responsive to the dietary $\mathrm{CP}$ level; however, the responsiveness seems to be coarser, or limited, compared to pepsin. These enzymes are not often reported in the stomach of fish (Cuvier-Péres, 2001), however, they are present in the stomach of Pseudoplatystoma corruscans (Lundstedt et al., 2004) as well as in jundiá (Melo et al., 2006).

Responsiveness of amylase to the content of dietary polysaccharides is only reported in fish (Kawai and Ikeda, 1972; Moraes and Bidinotto, 1995). In jundiá, amylase was induced by 
increasing levels of corn. Studies on matase activity of Sparus aurata and Carassius auratus have shown that this carbohydrase is affected by the source of dietary carbohydrate (Silva et al., 2010). The influence of diet processing (extrusion or pelletization) of wheat and corn on the nutritional characteristics of the feeding is also reported. Structural changes on the dietary starch can affect the enzyme activity of amylase as reported for pacu Pyaractus mesopotamicus (Honorato et al., 2009). The amylase activity of jundiá was similar in all sections of the gastrointestinal tract. Likewise, lipase was induced by the content of dietary lipids. Lipase was expressed in all gastrointestinal tract of jundiá and the degree of responsiveness was similar among all sections. The highest lipase activity was observed in the anterior section of the intestine, decreasing toward the posterior section. This indicates the intestine as the main site for lipid digestion. These results were similar to those reported on other fish species Scophthalmus maximus (Fu et al., 2005) and Boleophthalmus pectinirostris (Wu et al., 2007).

The induction of lipase through the content of dietary fat in the fish was observed in Tilapia mossambica (Nagase, 1964), Ctenopharyngodon idella (Das and Tripathi, 1991) and P.corruscans (Lundstedt et al., 2004). Therefore, the increase of carbohydrates and fat in the diet of jundiá raised the amylase and lipase activities. This fact can be properly used to adjust the content of these nutrients in the formulation of diets. Considering the sum of digestive enzymes and the response to the level of nutrients we assume that the best amount of dietary protein is near $27 \%$.

\section{CONCLUSIONS}

Changes in the level of dietary protein, carbohydrate and fat in the feeding of jundiá led to digestive adjustments. Gastric proteolysis was proportional to the dietary protein. The anterior intestine holds the chief amount of alkaline proteases, which are fully expressed at $27-34 \%$ crude protein. Amylase and lipase were responsive to the carbohydrate and fat contents in the feeding. The present data encourages measurements and adjustments of the protein/energy ratio to achieve the best yield in the nutrition of $R$. quelen.

\section{ACKNOWLEDGMENTS}

The authors are grateful to the colleagues at the Adaptive Biochemistry Lab for the logistical support. This paper was adapted from the Thesis submitted by José Fernando Bibiano Melo to Federal University of São Carlos-SP as partial fulfillment of the requirements for a Doctorate degree. This research was sponsored by FAPESP (São Paulo State Research Foundation), CAPES and CNPq (Brazilian Council of Research).

\section{REFERENCES}

ALBRO, P.W.; HALL, R.D.; CORBETT. J.T.; et al. Activation of nonspecific lipase (EC3.1.1.) by bile salts. Biochem. Biophys. Acta, v.835, p.477-490, 1985.

BERNFELD, P. Amylases $\alpha$ e $\beta$ : colorimetric assay methods In: Methods in Enzymology. Ed. Colowich. S.P. \& Kaplan. v.1. New York: Academic Press Inc. 1955, p.149-154.

CORRÊA, C.F.; DE AGUIAR, L.H.; LUNDSTEDT, L.M. et al. Responses of digestive enzymes of tambaqui (Colossoma macropomum) to dietary cornstarch changes and metabolic inferences. Comp. Biochem. Physiol., v.147, p.857-862, 2007.

CUVIER-PÉRES, A.; JOURDAN, S.; FONTAINE, P. et al., Effects of light intensity on animal husbandry and digestive enzyme activities in sea bass Dicentrachus labrax post-larvae. Aquaculture, v.202, p.317-328, 2001.

DABROWSKI, G.; KRUSMSCHNABEL, M.; PAUKKUT. M. et al., Cyclic growth and activity of pancreatic enzymes in alevins of artic charr (Salvelinus alpinus L.). J. Fish. Biol., v.40, p.511-521, 1992.

DAS, K.M.; TRIPHATI. S.D. Studies on the digestive enzymes of grass carp Ctenopharingodon idella. Aquaculture, v.92, p.21-32, 1991.

DE ALMEIDA, L.; LUNDSTEDT, L.; MORAES, G. Digestive enzyme responses of tambaqui (Colossoma macropomum) fed on different levels of protein and lipid. Aquacul. Nutrit., v.12, p.443-450, 2006.

FÄNGE, R.; GROVE, D. Digestion. In: HOAR, W.S.; RANDALL, D.J.; BRETT, J.R. (eds). Fish Physiology. Vol. VIII: Bioenergetics and growth. Academic Press. 1969. p.161-260.

FISH, G.R. The comparative activity of some digestive enzymes in the alimentary canal of tilapia and perch. Hydrobiol., v.15, p.161-179, 1960.

FU, X.H.; SUN, M.; SUN, S.C. Activity of digestive enzymes in Scophthalmus maximus. J. Fishery Scie. China, v.12, p.26-32, 2005. 
GLASS, H.J.; MACDONALD, N.L.; MORAN, R.M. et al. Digestion of protein in different marine species. Comp. Biochem. Physiol., v.91, p.607-611, 1989.

HOFFER, R.; SCHIEMER, F. Proteolytic activity in the digestive tract of several species of fish with different feeding habits. Oecologia, v.48, p.342-345, 1981.

HONORATO, C.A.; ALMEIDA, L.C.; SILVA NUNES, C. et al. Effects of processing on physical characteristics of diets with distinct levels of carbohydrates and lipids: the outcomes on the growth of pacu ( Piaractus mesopotamicus ). Aquacult. Nutrit., v.16, p.1-9, 2009.

HUMMEL, B.C.W. A modified spectrophotometric determination of chymottypsin. trypsin. and thrombin. Can. J. Biochem.Physiol., v.37, p.1393-1399, 1959.

INOUE, L.A.K.A.; SANTOS NETO, C.D.; MORAES, G. Clove oil as anaesthetic for juveniles of matrinxã Brycon cephalus (Gunther, 1869). Cienc. Rural, v.33, p.943-947, 2003.

KAPOOR, B.G.; SMITH. H.; VEREGHINA, I.A. The alimentary canal and digestion in teleosts. Adv. Mar. Biol., v.13, p.109-139, 1975.

KAWAI, S.; IKEDA, S. Studies on the digestive enzymes of fishes. II. Effect of dietary changes on the activities of digestive enzymes in carp intestine. Bull. Japan. Soc. Scent. Fish, v.38, p.265-270, 1972.

KHOLA, U.; SAINT PAUL, U.; FRIEBE, J. et al. Growth. digestive enzyme activities and hepatic glycogen levels in juvenile Colossoma macropomum Cuvier from South America during feeding. starvation and refeeding. Aquacult. Fisher. Managem., v.23, p.189-208, 1992.

KITAMIKADO, M.; TACHINO, S. Digestive enzyme of rainbow in pumpkinseed sunfish. Lepomis gibbosus. Chem. Abst., v.55, p.5789, 1960.

KUZ'MINA, V.V. Evolutionary features of the digestive-transport function in fish. Plenun Publishing Corporation. Translated from Zhurnal Évolyutsionnoi Biokhimii i Fiziologii, v.27, p.167-175, 1991.

KUZ'MINA, V.V.; SMIRNOVA, Y.G. Distribution of alkaline phosphatase activity along the length of the intestine of freshwater teleosts. J. Ichthyol., v.32, p.19, 1992. KUZ'MINA, V.V. Seasonal and age-related changes in $\alpha$-amylase activity in the bream. Abramis brama. J. Icthyol., v.20, p.105-109, 1981.

LOVELL, T. Nutrition and feeding of fish. New York: Chapman \& Hall. 1988, 259p.

LOWRY, D.H.; ROSENBROUGH, N.J.; FAR, A.L. et $a l$. Protein measurement with folin phenol reagent. $J$. Biol. Chem., v.193, p.265-275, 1951.
LUNDSTEDT, L.M.; MELO, J.F.B.; MORAES, G. Digestive enzymes and metabolic profile of Pseudoplatystoma corruscans (Teleostei: Siluriformes) in response to diet composition. Comp. Biochem. Physiol., v.137B, p.331-339, 2004.

McGOOGAN, B.B. and GATLIN III, D.M. Dietary manipulations affecting growth and nitrogenous waste production of red drum, Sciaenops ocellatus: I. Effects of dietary protein and energy levels. Aquaculture, v.178, p.333-348, 1999.

MELO, J.F.B.; RADUNZ NETO, J.; SILVA, J.H.S. et al. Desenvolvimento e composição corporal de alevinos de jundiá (Rhamdia quelen) alimentados com dietas contendo diferentes fontes de lipídios. Cienc. Rural, v.32, p.323-327, 2002.

MELO, J.F.B.; LUNDSTEDT, L.M.; METÓN, I. et al. Effects of dietary levels of protein on nitrogenous metabolism of Rhamdia quelen (Teleostei: Pimelodidae). Comp. Biochem. Physiol., v.145, Part A, p.181-187, 2006.

MOARES, G.; BIDINOTTO, P.M. Induced changes on the amylohydrolytic profile of the gut of Piaractus mesopotamicus (Holmberg, 1885) fed different levels of soluble carbohydrates its correlation with metabolic aspects. Rev. Ictiol., v.8, p.47-51, 1995.

MORISHITA, T.; NODA, H.; KITAMIKADO, M. On the activity of the digestive enzymes in cultured fish. J. Fac. Fishe., v.22, p.239-246, 1964.

MUKHOPADHYAY, P.K. Studies on the enzymatic activities related to varied patternof diets in the airbreathing catfish. Clarias batrachus L. Hydrobiol., v.52, p.235-237, 1977.

NAGASSE, G. Contribution to the physiology of digestion in Tilapia mossambica Peters. Digestive enzymes and the effects of diets on their activity. $Z$. Vergl. Physiol., v.49, p.270-284, 1964.

NORDLIE, F.G. Thermal acclimatiom and peptic digestive capacity in the black bullhead. Ictalurus melas. Amer. Midland Naturalist., v.75, p.416-424, 1966.

OFFICIAL Methods of Analyses. AOAC. 17.ed. Association of Official Analytical Chemists. Gaithersbrug. 1990.MD. USA. 1422p.

PARK, J.T.; JOHNSON, M.J. Submicro determination of glucose. J. Biol. Chem., v.249, p.149-151, 1949.

PIAIA, R.; ULIANA, O.; FELIPETTO, J. et al. Alimentação de larvas de jundiá (Rhamdia quelen). com dietas artificiais. Rev. Cienc. Nat., v.19, p.119131, 1997. 
SARATH, G.; DE LA MOTTE, R.S.; WAGNER, F.W. Protease assay methods. In: Beynon. R. J and Bond. J.S. (Eds.). Proteolitc Enzymes. A Practical Approach. Oxford University. Oxford. 1989. p. 22-55.

SEGNER, H.; ROSCH, R.; SCHMIDT, H. et al. Digestive enzymes in larval Coregonus lavaretus L. J. Fish Biol., v.35, p.249-263, 1989.

SILFVERGRIP, A.M.C. A sistematic revision of the neotropical catfish genus Rhamdia (Teleostei. Pimelodidae). Department of Zoology. Stockholm University and Department of Vertebrate Zoology. Swedish Museum of Natural History - Stockholm. 1996. 156p.

SILVA, F.C.P.; NICOLI, J.R.; ZAMBONINOINFANTE, J.L. et al. Influence of partial substitution of dietary fish meal on the activity of digestive enzymes in the intestinal brush border membrane of gilthead sea bream, Sparus aurata and goldfish, Carassius auratus. Aquaculture, v.306, p.233-237, 2010.
SMITH, H. Influence of temperature on the rate of gastric juice secretion in the brown bullhead. Ictulurus nebulosus. Comp. Biochem. Physiol., v.21, p.125-132, 1967.

WALTER, H.E. Proteinases: methods with hemoglobin. casein and azocoll as substrates. In: Bergmeyer. H.U. (Ed). Methods of enzimatic analysis. Vol. V. Verlag Chemie. Weinheim. 1984, p.270-277.

WU, R.X.; HONG, W.S.; ZHANG, Q.Y. et al., Studies on the activities of digestive enzymes of Chinese Black Sleeper (Boleophthalmus pectinirostris). J. Xiamen Univ., v.46, p.118-122, 2007.

XIONG, D.M.; XIE, C.X.; ZHANG, H.J. et al. Digestive enzymes along digestive tract of a carnivorous fish Glyptosternum maculatum (Sisoridae, Siluriformes). J. Anim. Physiol. Anim. Nutrit., v.95, p.56-64, 2011. 